Beyond the Metropolis 
STUDIES OF THE WEATHERHEAD EAST ASIAN INSTITUTE, COLUMBIA UNIVERSITY

The Studies of the Weatherhead East Asian Institute of Columbia University were inaugurated in 1962 to bring to a wider public the results of significant new research on modern and contemporary East Asia. 


\section{Beyond the Metropolis}

SECOND CITIES AND MODERN LIFE IN INTERWAR JAPAN

\section{Louise Young}

\section{प甲}

UNIVERSITY OF CALIFORNIA PRESS

BERKELEY LOS ANGELES LONDON 
University of California Press, one of the most distinguished university presses in the United States, enriches lives around the world by advancing scholarship in the humanities, social sciences, and natural sciences. Its activities are supported by the UC Press Foundation and by philanthropic contributions from individuals and institutions. For more information, visit www.ucpress.edu.

University of California Press

Berkeley and Los Angeles, California

University of California Press, Ltd.

London, England

(C) 2013 by The Regents of the University of California

Library of Congress Cataloging-in-Publication Data

Young, Louise, 1960-

Beyond the metropolis: second cities and modern life in interwar Japan / Louise Young.

p. cm. - (Studies of the Weatherhead East Asian

Institute, Columbia University)

Includes bibliographical references and index.

ISBN 978-0-520-27520-I (cloth : alk. paper)

I. Urbanization-Japan-History-2oth century. 2. Japan-

Social conditions-1912-1945. 3. Japan-Civilization-2oth century.

4. Japan-History-1912-1945. I. Title.

$\mathrm{HT}_{3} 84 \cdot \mathrm{J} 3 \mathrm{Y} 682 \mathrm{OI} 3$

$307.760952-\mathrm{dc} 23$

2012040341

Manufactured in the United States of America

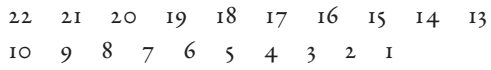

In keeping with a commitment to support environmentally responsible and sustainable printing practices, UC Press has printed this book on Rolland Enviroıo, a I0०\% post-consumer fiber paper that is FSC certified, deinked, processed chlorine-free, and manufactured with renewable biogas energy. It is acid-free and EcoLogo certified. 
In memory of

Rebecca Conrad Young 
This page intentionally left blank 